[街生動物 Vol. 41 No. 3 p. 247-255 1990]

\title{
高知県にわけるコガタアカイエカの発生動態 の特性と日本脳炎流行との関係
}

\author{
松崎 沙和子 \\ 高知女子大学生活生物学（幵780 高知市永国寺町 1-15）
}

（受領：1990年 2 月 8 日）

\begin{abstract}
Population dynamics of Culex tritaeniorhynchus in relation to the epidemics of Japanese encephalitis in Kochi Prefecture, Japan

Sawako MATSUZAKI

Department of Biology for Living, Kochi Women's University, Kochi 780, Japan
\end{abstract}

Key words: Culex tritaeniorhynchus, population dynamics, light trap, Japanese encephalitis, Kochi Prefecture.

\section{まえがき}

高知県における日本脳炎の疫学的調查を，患者数の多 かった 1966 年より厚生省の 委託事業として, 各県と歩 調を合わせて行ってきた。しかし，1975 年には患者数の 激诚にともなって事業が打ち切られたのでその後 8 年間 は調查を中止したが，1984 年に 熊本県などに 集中的に 患者が発生するに及んで再び調查を自主的に再開し，現 在まで継続してきた．調查開始より約 25 年に及び患者 も蚊数もともに減少した今日に，これらの時間的推移か ら日本脑炎媒介蚊のコガタアカイエカ Culex tritaeniorhynchus Giles と日本腷炎患者発生との 関連性や本種 蚊が疫学的に果たす役割，とくに高知県における特性を 明らかにしておくことは意義があると思われる。本県は 日本の西南域にあり，植生は亜熱帯型で，冬暖かく，春 から夏にかけての雨量の多いことなど蚊の発生に好適な 環境条件にあり，かつては典型的な日本脳炎多発地帯で あった. なかでも高知県中部の海岸線沿いに集中する水 田では，かつて二期作が行われるなど他県とは異なる環 境下にあった．そこで本論文では，この水田地带に隣接 した豚舎にライトトラップを設置して長期閒蚊の採集を 行い，媒介蚊を中心とした疫学調查や生理・生態学的研 究の結果を述べる.
調查方法

コガタアカイエカのライトトラップによる定期採集 高知市の東北部，浦戸湾奥近くにある比島町の豚舎 (B舎と呼称)において，地上 $2 \mathrm{~m}$ に吊り下げたライトト ラップ（野沢式；ブラックライト FL-6 W 管使用）に より 17 時より翌朝 7 時まで 毎週 1 回（金曜日）を原則 として，1975 年から 1981 年の 7 年間を除く，1966 年よ り 1989 年までの 17 年閒にわたり蚊の採集を行った. B 舎は高知市の中心街のはずれに位置し，調查点を設定し た当初は香長平野へと広がる広大な水田に面しており， 常時 2,000 頭の豚が飼育されているなど, コガタアカイ エカの探集にはいたって安定した環境にあり，さらに， 発生源と直結しているところから蚊の個体数の変動が正 確に把挃されやすい好適な立地条件にある(松崎, 1972). 近年の比島町は埋め立ては徐々に進行しているものの市 街地化が遅れており，その影響がきわめて少ない（Fig. 1). B舎の採集期間を日本脳炎患者, 蚊数ともに多かっ た 1966 年から 1973 年までの 8 年間を前期とし，その後 両者の激減した 1982 年から 1989 年に至る近年 8 年間を 後期として取り扱った．また患者発生がなかった 1974 年についてはこれらの期間から除外した. 蚊の同定はシ ロハシイエカ Culex pseudovishinui Colless などュガ タアカイエカと紛らわしい種の混入のおそれがあるため に調查開始時に検討を行ったところ，初春と晚秋に数個 


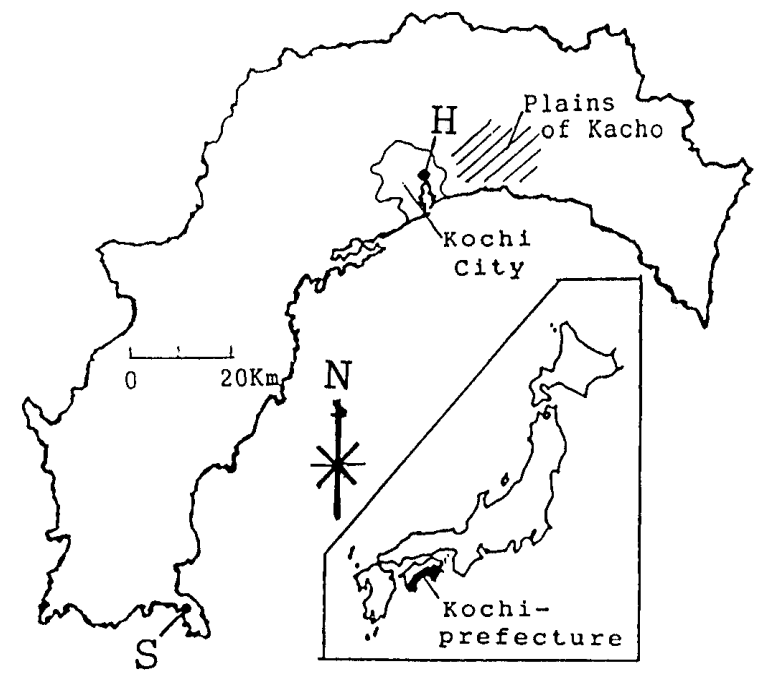

Fig. 1 A map showing mosquito sampling sites by light traps in Kochi City and Tosashimizu City, Kochi Prefecture, Japan.

$\mathrm{H}$ : Hijima-cho (main site), Kochi City ; S: Tosashimizu City.

体それらしい個体が認められたが，破損が激しい場合が 多く確認は困難であったので，すべて不明種として取り 扱った。

高知市におけるコガタアカイエカ幼虫世代数の推定 高知での幼虫世代数を知る目的で $15,20,25,30^{\circ} \mathrm{C}$ の飼育温度区を設定（日長時閒 16 時間）し，さらに水 $500 \mathrm{ml}$ あたり卯孚化直後の幼虫 $10 ， 20 ， 50 ， 100 ， 200$, 400 個体の各密度区を設け，幼虫の発育を観察した。こ の飼育結果から発育零点を求め, 斎藤 (1986) の方法に より有効積算温度を算出し, 高知市の気象台による気温 を当てはめて幼虫世代数を推定した.

\section{コガタアカイエカの成虫採集個体群に及ぼす気象要因 の影響}

コガタアカイエカのライトトラップでの採集個体数の 多少が高知の気象, とくに冬期の気温, 梅雨期の降水量 とかかわりがあるのではないかとの推定のもとに高知市 の気象台資料を用いて 検討した．また，土佐清水市で 1968 年から 1971 年の 4 年間, 高知市と類似した環境下 にある豚舎で同様の方法で採集を行った結果をむ加え た. 同市は高知県の最南端にあり気象上から高温で冬暖 かいのが特徴である.

コガタアカイエカの飼育時の日長条件とライトトラッ

\section{プへの走性と吸血反応との関係}

本種蚊が 9 月上旬にライトトラップに急激に採集され なくなるのは，この時期の気温が活動の低下を決定づけ るほどのものではないところから，日長条件がおもな決 定要因とみなされる．そこで光に対する走性の室内実験 を行った．実験区には直径 $20 \mathrm{~cm}$ のバットに深さ $5 \mathrm{~cm}$
まで水を入れ，1齢幼虫を 150 個体放し，昆虫用固型飼 料とエビオスを等量配合した慨を与えて， $25^{\circ} \mathrm{C}$ と $20^{\circ} \mathrm{C}$ の空調室内で 14.5 時間と 10.0 時閒の照明および全暗黒 の 3 段階の日長下で成虫まで飼育した. 対照区は $28^{\circ} \mathrm{C}$, 14.5 時間照明とし，他の条件は実験区と等しくして 飼 育を行った. これらの条件で飼育した幼虫を羽化させた のち，第 1 の観察として成虫を幼虫期と同じ環境条件で 飼育し, 羽化後 5 日目に野外観察で用いているライトト ラップの光源ランプに対する走性と, 当研究室で通常吸 血に供している孵化後 2 日目のヒヨコへの吸血状態を観 察した．第 2 の観察として，幼虫時に対照区の条件で飼 育して得られた成虫を実験区の各温度と短日条件の 10 時間照明に移し，同様の吸血行動と光に対する反忍を観 察した.

コガタアカイエカの越冬と日本脳炎ウイルス保有状況 本研究当初よりコガタアカイエカの越冬個体の確認作 業を都市部では神社仏閣, 人家の床下や壁の割れ目, 排 水口, 地下道などで, また，農村部で汇河川の堤，草原 など潜伏の可能性のある場所について冬期から春先にか けて毎年精力的に調查を行った. この他に越冬蚊の潜伏 の可能性がある場所として高知県下の数多くの洞窗が考 えられたので, 入洞可能な猿田洞, 穴岩洞, 石土洞, 白 岩洞, 葛蒲洞, 伊尾木洞の 6 力所の越冬蚊を調査し, 採 集された蚊からウイルスの分離を試みた。

\section{その他}

高知県における日本脳炎発生状況は高知県保健環境部 医務課の資料によった. また，気象データはB舎から 300 $\mathrm{m}$ の距離にある高知市気象台による観測值を用いた.

\section{結果}

\section{1. 採集蚊の種構成と季節的消長}

1) 種 構 成

$\mathrm{B}$ 舎のライトトラップで採集された蚊個体数と種構成 比は，1966 年ではコガタアカイエカ 39,678 (77.6\%)， アカイエカ Culex pipiens pallens Coquillett 7,863 (15.4\%), シナハマダラカ Anopheles sinensis Wiedemann 3,602 (7.0\%), 不明種 11 (0.02\%) であった が，1989年はコガタアカイエカ 3,598 (99.4\%)，アカ イエカ, $20(0.6 \%)$ ，シナハマダラカ $3(0.08 \%)$ と 近年は蚊の総採集数が減少するとともにアカイエカ, シ ナハマダラカの減少が目立っている.

2）コガタアカイエカ採集数の変動と日本脳炎流行と の関係

全調查期閒を通じてコガタアカイエカの最盛期である $5 \sim 9$ 月の採集総数をこの期間の採集回数で除した值 (以後は日平均採集数と記す) で示すと高知県下の日本脳 
炎確認患者数の変動はこれとよく似た増減傾向を示し， 両者の間には $r=0.949$ と高い相関係数が得られた (Fig. 2). 1966 年ころ，蚊の日平均採集数は 5,000匹に 達していたが，1972 年以降は 1,000 匹以下に 急速な 減 少をたどっている. 調查前期 8 年間の香長平野の総作付 水田面積や二期作作付面積と 5 9 月の 5 カ月の日平均 採集数との間には相関が認められ，相関係数は前者で 0.757 ，後者では 0.738 であった (Fig. 3).

3）コガタアカイエカの季節的消長

本種蚊の高知県における季節的消長は，前期 8 年間は 高知県における蚊の採集数が多い時代の典型的な傾向が みられ，その後採集数は著しく減少している (Fig. 4). しかし, 調査後期でも減衰したとはいえ, 活動最盛期で は一晚に数百から数千の個体が採集され続けている。調 查前期での一晚の最大採集数は 2 万程度であったが，風 雨の強い日は極端に減少するのが常であった.このよう に採集個体数の多かった前期の典型的な季節的消長から 高知県の発生様相の特徵をあげると次のようになる，2 月ころ作られる水田の苗代に幼虫が見られ始める 3 月下 旬に，ライトトラップヘ1ないし数個体の雌が採集され るようになり，その後 4 月下旬から個体数を増し， 6 月 から 7 月にかけてピークを形成し，9月第 1 週には急速 に滅少して 10 月下旬にはまったくみられなくなる.

調查期間中のコガタアカイエカの初採集日は日平均気 温 $10^{\circ} \mathrm{C}$, 最高温度 $15^{\circ} \mathrm{C}$ くらで, 例年春の彼岸前後 であり，平均気温 $15^{\circ} \mathrm{C}$ に上昇する 4 月上旬まで翅長が 長い越冬蚊とみなされる個体が多く採集される。

\section{2. 高知市における幼虫世代数の推定}

幼虫の発育零点は雌で $18.4 \sim 4.8^{\circ} \mathrm{C}$ と飼育密度によ り差がみられ，高密度ほど低温となった（Table 1).こ れらの值から高知市における幼虫発生世代数を算定する
と 6 世代と推定された.

\section{3. コガタアカイエカの成虫採藮数に及ぼす気象要因 の影誉}

本種蚊は成虫越冬する昆虫であるところから冬期の気 温は次年の蚊発生に大きく影㹕すると考えられる。そこ で 1966 年から 7 年間の 各年に 採集された総採集数と前 年の 12 月から 次年の 3 月までの 4 カ月の平均気温との 関係をみると, $7 \sim 8{ }^{\circ} \mathrm{C}$ を越えた 3 年間は1966年

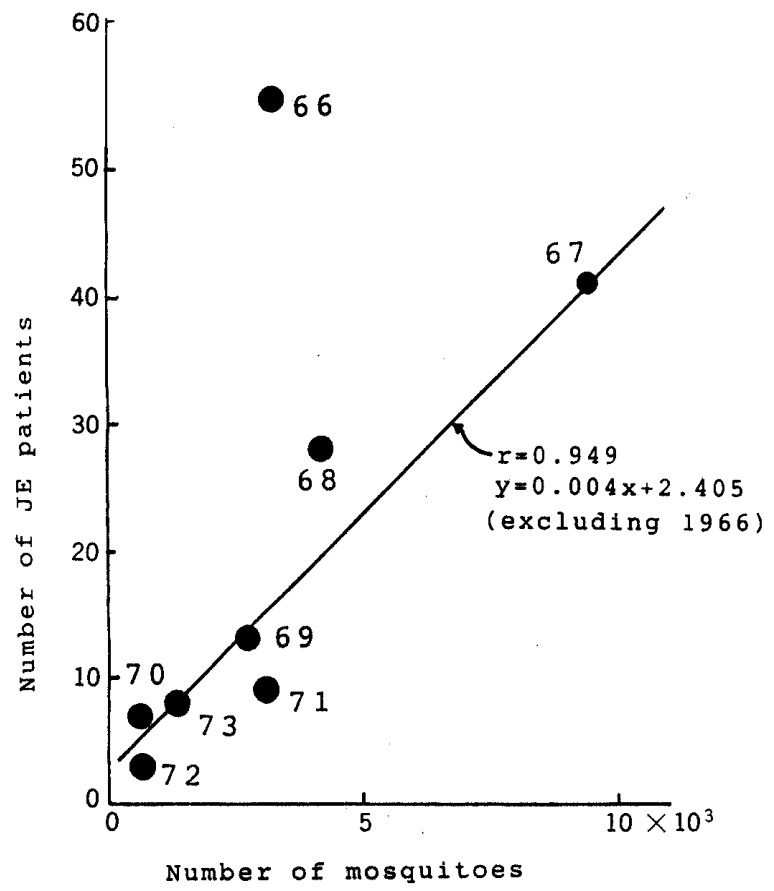

Fig. 2 Correlation between the number (per trap-night) of $C x$. tritaeniorhynchus collected from May to September and the number of Japanese encephalitis cases in Kochi Prefecture from 1966 to 1973 .
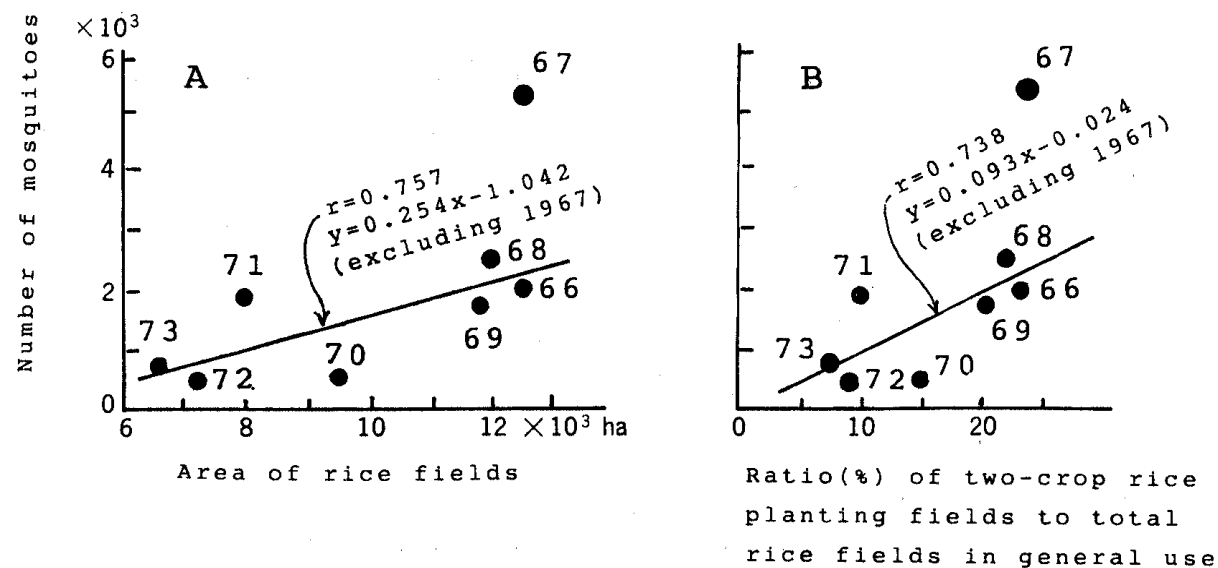

Fig. 3 Correlation between the number (per trap-night) of Cx. tritaeniorhynchus collected from May to September and the total area of rice fields (A) or the proportion of two-crop rice planting fields (B) in Kacho Plain in Kochi. 

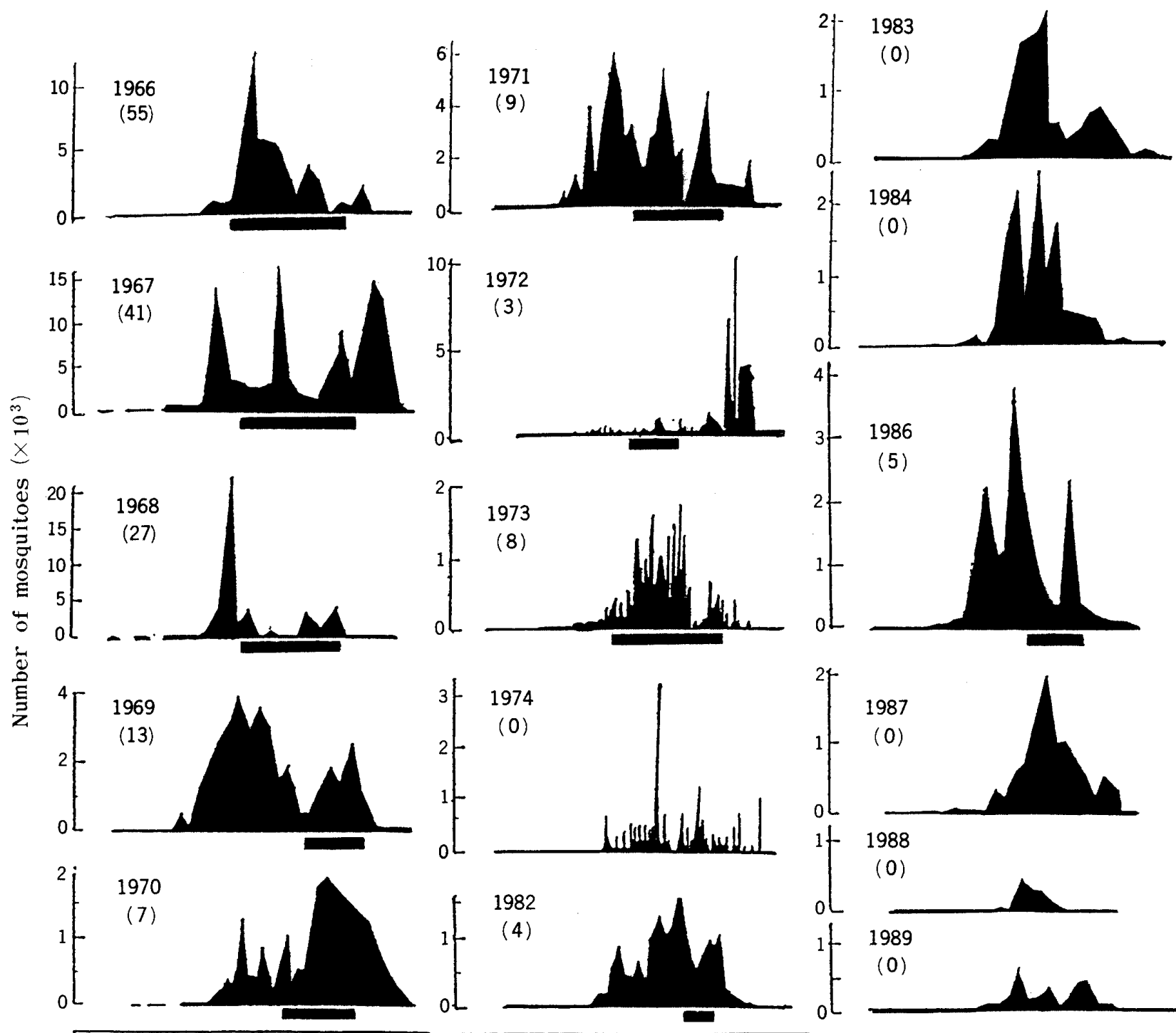

M.'A.'M.'J.'J.'A.'S.'O. TM.'A.'M.'J.'J.'A.'S.'O.

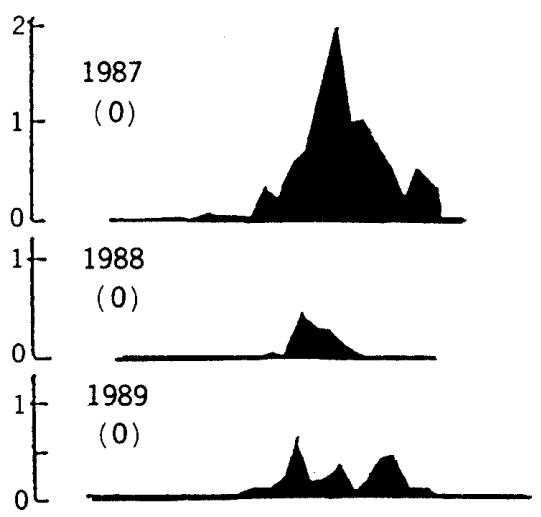

Fig. 4 Seasonal prevalence of Cx. tritaeniorhynchus collected by light traps at Hijima-cho in Kochi City, Japan, from 1966 to 1989, excluding 1975 to 1981 and 1985.

Horizontal bar under the figure indicates period of JE outbreak in each year. Number of JE patients is shown in the parenthesis.

$(119,762$ 匹)，1967 年 $(115,943$ 匹)，1969 年 $(116,657$ 匹）ときわめて多くの個体が採集されたのに対して，残 りの調查各年は， $6 \sim 6.5^{\circ} \mathrm{C}$ もしくはそれ以下の低気温 であって，たとえば 1968 年 $(33,750$ 匹)，1970年 $(33,650$ 匹）のように $1 / 3$ 以下の採集数であった.

さらに，4，5月の総降水量はその年の 6 月の日平均採 集数に影響し，この時期雨の多いことは採集数を増すよ うに働くようである (Fig. $5 \mathrm{~A}$ )。この傾向は土佐清水 市でより明瞭であった. 1971 年を除く 1970 年以降は急 激に採集数が減少するので Fig. 5 A には記入してない が，採集数が少ないなかでも降水量との相関が認められ た.またこれとは逆に 6 月の雨量が多すぎると日平均 採集数は減少した (Fig. 5 B).
4. コガタアカイエカの飼育時の日長条件とライトト ラップへの走性と吸血反応との関係

幼虫時期から短日条件 (10 時間照明および全暗黒) の 実験区では吸血率 0\%で, 光に対して正の反応を示した 個体は日長 10 時間で 10〜18\%認められたのみであった (Table $2 \mathrm{~A}$ ). 一方, 幼虫期を長日高温下で飼育した成 虫を短日条件下に移した場合は，光に対して $100 \%$ 近い 正の走性を示し, 吸血率も 92〜96\%の高い值を示した (Table 2 B).

5.コガタアカイエカの越冬と日本脳炎ウイルス保有 状況

都市部の 神社仏閣，人家の床下や壁の割れ目，排水 口, 地下道, 農村部の河川の堤, 草原など調查前期に毎 
年 30 日以上，延べ 240 日以上， 1 回に数人から十数人で 調查したにもかかわらず，越冬蚊は採集できなかった. 一方, 洞窟の調查ではコガタクロウスカ Cx. hayashii Yamada が猿田洞 (14匹), 穴岩洞 (6匹), 石土洞 (4 匹)，ミナミハマダラウスカ Cx. mimeticus Noé が白岩 洞 (11 匹) 菖蒲洞 (11 匹), さらにアカイエカが伊尾木 洞 (26匹) から発見されたが，どの洞窟からもコガタア カイエカは採集できなかった，また，洞篃内探集越冬蚊 についてウイルスの分離を試みた結果, すべて陰性であ った.

Table 1 Temperature of developmental zero and the regression equation of developmental period for larval and pupal stages of Cx. tritaeniorhynchus rearing under the different initial larval densities in $500 \mathrm{ml}$ of water.

\begin{tabular}{ccc}
\hline Density & $\begin{array}{l}\text { Regression } \\
\text { equation }\end{array}$ & $\begin{array}{l}\text { Temperature of } \\
\text { developmental } \\
\text { zero }\left({ }^{\circ} \mathrm{C}\right)\end{array}$ \\
\hline \multirow{2}{*}{50} & $y=0.065 x-0.079$ & 12.2 \\
& $y=0.011 x-0.202$ & 18.4 \\
\multirow{2}{*}{100} & $y=0.035 x-0.025$ & 7.1 \\
& $y=0.004 x-0.039$ & 9.6 \\
200 & $y=0.003 x-0.097$ & 3.7 \\
& $y=0.028 x-0.013$ & 4.8 \\
\hline
\end{tabular}

Table 2 Blood-feeding activity and phototaxis of female $C x$. tritaeniorynchus reared at different daily photoperiod and temperature during the larval and pupal stages.

A

\begin{tabular}{|c|c|c|c|c|c|c|}
\hline \multirow{2}{*}{$\begin{array}{l}\text { Day } \\
\text { length }\end{array}$} & \multirow{2}{*}{$\begin{array}{l}\text { Temper- } \\
\text { ature } \\
\left({ }^{\circ} \mathrm{C}\right)\end{array}$} & \multirow{2}{*}{$\begin{array}{l}\text { No. } \\
\text { reared }\end{array}$} & \multicolumn{2}{|c|}{$\begin{array}{l}\text { Blood- } \\
\text { sucking }\end{array}$} & \multicolumn{2}{|c|}{$\begin{array}{l}\text { Positive } \\
\text { phototaxis }\end{array}$} \\
\hline & & & No. & $\%$ & No. & $\%$ \\
\hline \multirow[t]{3}{*}{14.5} & 28 & 125 & 121 & 96.8 & 125 & 100.0 \\
\hline & 25 & 125 & 120 & 96.0 & 122 & 97.0 \\
\hline & 20 & 125 & 125 & 100.0 & 125 & 100.0 \\
\hline \multirow[t]{2}{*}{10.0} & 25 & 125 & 0 & 0 & 23 & 18.4 \\
\hline & 20 & 125 & 0 & 0 & 12 & 9.6 \\
\hline 0 & 20 & 125 & 0 & 0 & 0 & 0 \\
\hline
\end{tabular}

B

\begin{tabular}{|c|c|c|c|c|c|c|}
\hline \multirow{2}{*}{$\begin{array}{l}\text { Day } \\
\text { length }\end{array}$} & \multirow{2}{*}{$\begin{array}{l}\text { Temper- } \\
\text { ature } \\
\left({ }^{\circ} \mathrm{C}\right)\end{array}$} & \multirow{2}{*}{$\begin{array}{l}\text { No. } \\
\text { reared }\end{array}$} & \multicolumn{2}{|c|}{$\begin{array}{l}\text { Blood- } \\
\text { sucking }\end{array}$} & \multicolumn{2}{|c|}{$\begin{array}{l}\text { Positive } \\
\text { phototaxis }\end{array}$} \\
\hline & & & No. & $\%$ & No. & $\%$ \\
\hline 10.0 & 25 & 125 & 120 & 96 & 125 & 100.0 \\
\hline 10.0 & 20 & 125 & 115 & 92 & 125 & 100.0 \\
\hline
\end{tabular}

A : Mosquitoes were reared at different daily photoperiod and temperature from the larvae to the adults. B : Larvae and pupae were reared at $28^{\circ} \mathrm{C}$ and $14.5 \mathrm{hr}$ day length. The adults were transferred to lower temperatures at short day length $(10 \mathrm{hr})$.
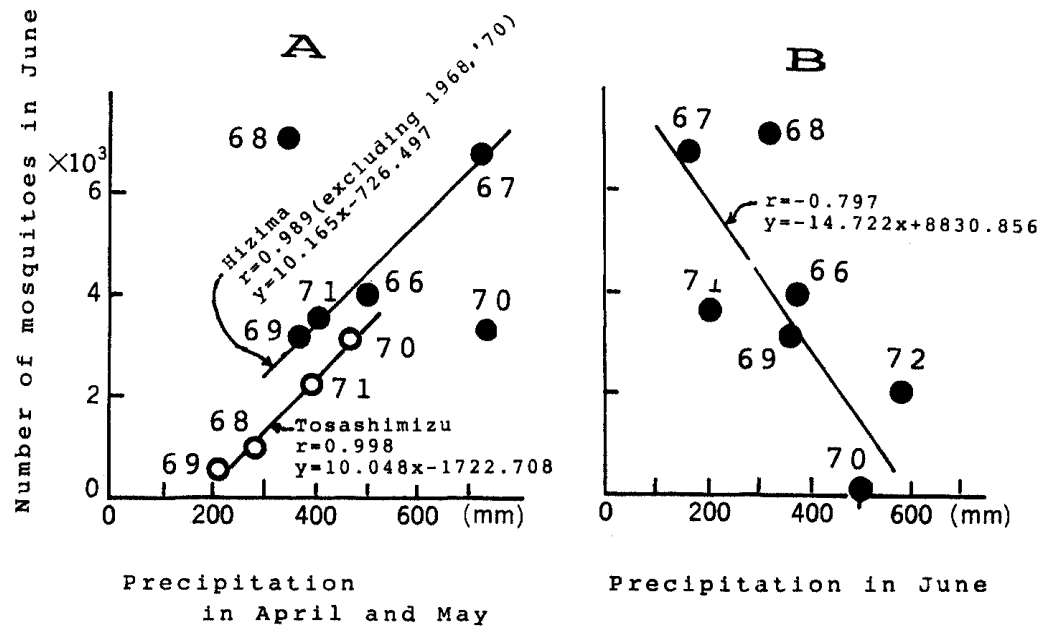

Fig. 5 Correlation between the number of $C x$. tritaeniorhynchus collected at Hijima-cho and at Tosashimizu City and precipitation in Kochi City, Japan.

A: Correlation between the number of mosquitoes (per trap-night) in June and the total precipitation in April and May. B : Correlation between the number (per trap night) of mosquitoes in June and the total precipitation in June. 


\section{考察}

\section{コガタアカイエカの発生動態と患者発生}

調查前期はコガタアカイエカが $80 \%$ 近くを占める主 要種であったことは，水田に面したライトトラップで集 められる蚊の一般的な傾向で，原田（正）ら（1987）の 岡山県の水田地帯での結果と近似している. 高知のB舎 周辺は水田に直接接しており，アカイエカの発生水域で ある家庭排水の流入する側溝が少ないことから，水田に 発生するコガタアカイエカが主要種であったとみられ， その地域の水域の特徵を反映しているとみられる。

コガタアカイエカの年間総採集数の変動は, 岡山県の 1955 年に始まる長期観察結果（原田（正）ら，1987）か らすると本調查開始の 1966 年はすでに蚊個体数の激減 期に入っていたようで，本邦の日本脳炎患者数が 2,000 名を越えていた時代から 2 けた時代への移行期に当たっ ている．高知県下の患者数は 1973 年ころまでは 2 けた で推移し，1974 年ころから0名ないし数名へと減少し ている。現在なお，豚の $\mathrm{HI}$ 抗体保有率の上昇が時期的 には遅れる傾向にありながら $50 \%$ に到達することから， 日本脳炎污染地域に指定されているのが現状である。高 知県の患者発生は Fig. 4 にみるように, 調查前期での 最初の 3 年間の患者が多かった時期は，6月中旬に始ま り9月まで継続するのが通常である，蚊の発生が減少す るに及んで患者の数も減少しており，発生は遅れる傾向 にある。

調查前期の香長平野の総水田作付面積とさらに二期作 作付面積と， 5〜9月の日平均採集数との間には Fig. 3 に示したように高い相関が認められたことから, 高知 の二期作は長時間水田に水を張ることになり, 蚊の発生 を助長していたとみられる，近年では二期作慣行はまっ たく行われていないが，台風対策のために作付時期を 1〜2力月早めている水田があることも, 幼虫発生に一 役買っているとみられる. しかし, 水田には殺虫剤, 除 草㓮が多量に使用され，さらに機械導入など農耕様式の 変化（上村·香取, 1969 ; 上村・渡辺，1973）の影響が かなり大きいとみなされ，これらの総合された影響によ り近年の蚊発生の減少があるむのと考えられる.

本種の高知での季節的消長は, 調查前期は発生, 最盛 期ともに本州よりほぼ 1 力月早く現れる発生型がみられ たが, 調查後期は個体数が減少し, 明らかなピークは現 れないか，またはその時期が遅れる型に移行している (Fig. 4). 高知県の最南端足摺岬の近くに位置する土佐 清水市では, 高知市周辺より約半月早い最盛期がみられ る（松崎，1972）。一方, 愛媛県 (森川ら, 1965), 徳島 県(石井・唐牛，1976)では岡山県に似た季節的消長を示
し，四国山脈を境に発生のずれがみられる，全国的にみ るとコガタアカイエカの最盛期の到来は, 通常, 南から 北へ遅れながら移行している. 関西地方は一般に 5 月下 旬に越冬雌が出現し，7 月下旬にピークを形成し，8 月 下旬から 9 月上旬にかけて活動を停止する(松尾, 1958 ; 武衛ら, 1968 ; Yamamoto and Manako, 1968 ; Maeda et al., 1977). これに対して九州北部と米子地方では 4 月下旬に越冬雌は出現しているが， $5 \sim 6$ 月下旬までほ とんど成虫は採集されず，8月上旬に顕著な峰を作り中 旬以降は減少寸る（大利・下釜，1953; 長花・外山， 1958 ; 伊藤, 1964). 中部地方は京都地方と大差ない（真 喜屋，1971). 関東地方の川崎市ではこれに近い発生で ある（緒方，1959）が，北部においては遅れがみられ， 米子地方に近い発生様相である（倉茂，1965）.

コガタアカイエカの成虫採集数に影郬を及ぼす気象要

\section{因と発生世代}

高知県では平均気温が $15^{\circ} \mathrm{C}$ に上昇する 4 月上旬まで 越冬蚊とみなされる個体が多く採集されるが，これらは 休眠覚醒後吸血可能な気温下ではじめてライトトラップ に採集されるようになったものであろう。一方，活動の 終息については，とくに注目されるのは全国的にほぼ時 を同じくして 8 月下旬から 9 月上旬に採集数が急速に減 少し始めることで，本州北部の発生の終息期と高知県と で大差ないことである，その時期の気温は高知で 6 月 とほほ同じであるところから影響を与えている環境要 因としては日長条件が大きいと考えられる．Eldridge (1963), 伊藤ら (1968), Kawai (1969)，吉田ら（1969） は短日条件下では長日条件下より幼虫の発育が遅れる傾 向があり，休眠に関する臨界日長時間を 13 時間と 14 時 間の間としている。晨時間を 14.5 時間から0 時間ま で変化して幼虫を室内飼育した今回の実験結果からは, 10 時間より短日の場合明らかに吸血抑制が認められた。 これらの実験結果と季節的消長の傾向から本種蚊の活動 は日長時間に左右されるとみなしうる。

日長時間 10 時閒以下の短日下で発育した幼虫から羽 化した成虫は，光に対して正の走性を示さなくなること からも，休眠個体の出現によりライトトラップでの採集 数が水田内の幼虫発生数に比べて極端に減少するものと 考えられる。

室内で密度別に室温を変えて卵から成虫羽化，産卵ま で飼育することにより求めた発育零点，有効積算温度と 日平均気温を適用して野外の幼虫・蛹発育世代を推定し たところ 9 月までに 6 世代と考えられた。 6 世代目に相 当する幼虫は水田に見られるが，この世代は羽化後は越 冬蚊になるとみなされ，5世代までの成虫がライトに飛 来するものと考えられる. 1966 年の例では 6 月の個体数 
Vol. 41 No. 31990 年

急増期は第 2 世代目の幼虫から羽化した成虫に当たり， 7 月の最盛期は 3 世代目によるものであって，患者発生 と関係する世代は $3 ， 4$ 世代目と推定される。原田(文) ら（1964）も，神奈川県でライトトラップで採集した蚊 の季節的消長に現れるピークの回数より同様に 6 世代と しており，直接日本腷炎伝播と関保のある蚊の世代注第 3，4世代目とみなしている.これは高知県とほぼ同様 の傾向であるが，高知ではこれらの世代は約 1 カ月早く 発生する. 秋の減衰期は $5 ， 6$ 世代目の成虫に当たり， この成虫からの幼虫は 9 月に発育することになり，成虫 に変態しにくいかもしくは羽化したとしても吸血活動は ほとんどないとみなされる.

次に, Fig. 5 に示すように 4，5月の降水量が，その 年の最盛期の蚊採集数に影響している。これと逆に 6 月 の雨量は多すぎると同月の採集数を減少させる．Mogi （1978）が，本種蚊の大発生の 原因の一つとして7月に おける高温少雨をあげているのは，高知の 6 月に相当す る現象と考えられ興味ある指摘である.

\section{コガタアカイエカの越冬妏の採集}

高知県内の洞窟内などでコガタアカイエカの越冬個体 はまったく採集されず，越冬の実態は不明のままであ り，原田（文）ら（1964）の横須賀市と逗子市などで行 った洞窟やビニールハウスなどでの調查と同様の結果で あった. ただし，高知県の気象の特徽として毎年 2 月に 春を思わせる陽気の日が数日から 1 週間くらい続くこと があるが，この時期に蚊の個体数が多かった 調查前期 に，少数の越冬蜘が水田に近い人家内に飛来することを 観察しておりり,これらの蚊の越冬場所は人家付近にあっ たとも考えられる.

また，洞窟内で採集されたコガタアカイエカ以外の越 冬蚊についてウイルスの分離を行った結果, 感染蚊は得 られなかった，大谷（1985）は，日本の蚊から分離され るアルボウイルスが東南アジアのそれと近縁関係にある ことから，渡り鳥による日本への導入の可能性があると 述べているが，高知県で患者が南西地城からまず発生す る事実，また日本全域からみると流行の初発地が西日本 の各地に点在することからすれば，この説も考慮する必 要があるかもしれない。

\section{ま と め}

高知市の特定の豚舎において 1966 年より 1989 年ま で， 1975 年から 1981 年の 7 年間を除く合計 17 年閒ラ イトトラップにより蚊類の採集を行い，コガタアカイエ カについて日本脳炎患者発生様相などとのかかわりにお いて発生動態, 気象条件, 走光性, 蚊の越冬について調 查・考察した:
1. 採集された蚊は，調查前期にコガタアカイエカが 圧倒的に多く，次いでシナハマダラカが多く，アカイエ カは僅少であった. 後期にはこの 3 種ともに減少した が，とくにシナハマダラカでその傾向は顕著であった.

2. コガタアカイエカの $5 \sim 9$ 月の日平均操集数と日 本脑炎患者数の年間変動はよく似た増減傾向を示し, 調 查後期は採集蚊数の減少と並行して患者数が激減した.

3. 蚊数の多かった調查前期には香長平野の総作付水 田面積, 二期作作付面積と 5 9 月の日平均採集数とは 高い相関が認められた。

4. 高知市の豚舎でのコガタアカイエカの季節的消長 は，調查前期の 1966 年に典型的な盛夏単峰型がみられ， 1972 年ころまでは $6 ， 7$ 月に最盛期がみられた. その後 は発生のピークが遅れるなど，明らかなピークを示さな い年もみられるようになった。

5. 調查前期での幼虫発生世代数は 6 世代と 推定さ れ, 調查前期は蚊の最盛期は 3 世代目の幼虫から羽化し た個体によるものと推定された.

6. 秋期に気温は $25^{\circ} \mathrm{C}$ 以上を保っているにもかかわ らずライトトラップに本種蚊が採集されなくなるのは， 8 月下旬頃からの短日条件により羽化した成虫が吸血反 応を示さなくなり，さらに光に正の走性を示さなくなる ことによることを室内実験で確認した.

7. 前年 12 月から 3 月までが平均気温 $7^{\circ} \mathrm{C}$ 以上の年 は，蚊の発生がきわめて多い傾向にあった．また，4， 5 月の総雨量が多、年は最盛期の採集数が増大するが, 蚊の最盛期である 6 月に雨量が多いと採集数は減少し た.

8. コガタアカイエカは洞窟内をはじめ他の場所の調 查で発見されず，越冬状態は確認できなかった。 また他 種の越冬蚊からもウイルスは分離できなかった。

蚊からのウイルス分離を担当され絶大なご協力をいた だいた高知県衛生研究所の出口祐男博士，ご校閲を賜っ た岡山大学の石井 明教授, 岡山大学医療短期大学部頓 宮廉正教授ならびに、ご助言いただいた長崎大熱帯医学 研究所の和田義人博士, 予防衛生研究所所長大谷 明博 士，前田 理博士，さらに長年の野外採集や標本整理に ご協力いただいた野田和子氏や当研究室の関係者に深く 感竘の意を表します.

\section{引用文献}

武衛和雄, 新井 浩, 上羽 界, 中島貞夫, 前田章 子（1968）: 大阪府に扣けるコガタアカイエカの 生態と日本稱炎ウイルス保有状況に関する研究. 衛生動物, $19: 237-248$.

Eldridge, B. F. (1963) : The influence of daily 
photoperiod on blood-feeding activity of Culex tritaeniorhynchus Giles. Am. J. Hyg., 77 : 49-53.

原田文雄，小林一郎，森谷清樹（1964）：日本脳炎 の疫学に関する野外実験 (3).1963 年度神奈川県 衛生研究所年報, $151: 84-91$.

原田正和，村主節雄，板野一男，頓宮廉正，安治敏 樹，王 炳楠，稲臣成一 (1987)：岡山県の市街 地におけるライトトラップによる捕集蚊数の年次 変化. 衛生動物, $38:$ 197-202.

石井 孝, 唐牛良明 (1976) : トラップ採集による 蚊個体群の動態解析。2. 同一場所で同時に採集 した標本個体間の比較. J. Sci., Univ. Tokushima, 9 :'15-56.

伊藤寿美代（1964）：長崎市内の 4 地区に於ける Light trap による蚊類の採集成績. 長崎大風士病 紀要, $6: 231-241$.

伊藤寿美代，中村 央, 吉田政弘 (1968)：日本脳炎 に関する研究（第 5 報）。大阪府立公衆衛生研究 所研究報告, $6: 91-94$.

上村 清, 香取幸治（1969）: 富山県におけるコガ タアカイエカの消長と農薬空中散布の影響および 日本脳炎流行との関連. 衛生動物, $20: 87-94$.

上村 清, 渡辺 護 (1973): 日本脳炎媒介蚊の激 減を導いた農薬の近代化について。防虫科学, 38 : 245-253.

Kawai, S. (1969): Studies on the follicular development and feeding activity of the females of Culex tritaenorhynchus with special reference to those in autumn. Trop. Med., 11 : 145-169.

倉茂好雄（1965）: 1965 年度宇都宮市における蚊の 季節的消長と同市周辺における日本脳炎の発生. 宇都宮大学教育学部紀要, $17: 118-125$.

Maeda, O., K. Takenokuma, Y. Karoji and Y. Matuyama (1977) : Epidemiological studies in Japanese encephalitis in Kyoto City area, Japan. I . Evidence for decrease of vector mos. quitoes. Jpn. J. Med. Sci. Biol., 31 : 17-37.

真喜屋清 (1971)：名古屋地方における蚊族個体群 の発生動態 II. 1968年名古屋市内の水田地帯にお ける蚊族幼虫および成虫個体群. 衛生動物, 22 : 31-38.

松尾喜久男（1958）：Light trap に捕集される蚊 成虫相の周年遷移について。防虫科学, $23: 23$ 27.

松崎沙和子 (1972): 高知県のコガタアカイエカの 季節的消長について特に気象と耕作状況との関係 について. 衛生動物, 22:238 (講演集).

Mogi, M. (1978) : Population studies of mosquitoes in the rice field area of Nagasaki, Japan, especially on Culex tritaeniorhynchus. Trop. Med., 20 : 173-263.

森川国康，小野鄉一，森脇昭介，西田 弘，石川和 男，芝実，松本礼三枝 (1965) : 1965年度受 媛県下に打ける日本檤炎媒介蚊コガタアカイエカ の季節的消長について。東需短期大学研究論集,
$2: 69-84$.

長花 操, 外山宽樹 (1958)：米子における蚊の季 節的消長 (昭和 $29 \sim 31$ 年の調查). 衛生動物, 9 : 5-15.

緒方一喜（1959）：川崎市における蚊成虫の周年調 查. 衛生動物, 10:179-183.

大利茂久，下鉒 勝 (1953) : 長崎市内の牛舎に於 ける蚊族の季節的消長. 1 . 昭和 27 年の成績. 長 崎大学風土病研究業績, $170: 1020-1953$.

大谷 明 (1985)：改めて日本脳炎を考える.感染・ 炎症・免疫, $15: 1-8$.

斎藤哲夫 (1986)：新応用昆虫学, p. 56 , 朝倉書店, 東京.

Yamamoto, H. and K. Manako (1968) : Seasonal prevalence and natural infection of the vector mosquitoes of Japanese encephalitis virus in the Fukuoka area, 1964 and 1965. Jpn. J. Sanit. Zool., 19 : 4-14.

吉田正弘, 外村勝之, 中村 央, 武衛和雄, 藤戸貞 男，大津啓二，大石 功 (1969)：日本腷炎の疫 学に関する研究 (第 6 報). II. 市街地に打ける 蚊採集成績. 大阪府公衆衛生研究所研究報告公衆 衛生編， $7: 85-88$.

\section{Summary}

Mosquitoes were collected by light traps at a pigstay near paddy fields in Kochi, Japan, during 9 years from 1966 to 1974 and 8 years from 1982 to 1989.

Major species were Culex tritaeniorhynchus (77.6\%), Anopheles sinensis (7.0\%) and Cx. pi. piens pallens $(15.4 \%)$ in 1966. However, the population size was gradually reduced especially in latter two species in recent 1980s.

$C x$. tritaeniorhynchus was caught through the end of March to mid-October, and it showed a peak of occurrence in June and July in 1966 and subsequent several years. Six larval generations were estimated in a year.

A high degree of correlation was observed between the number of $C x$. tritaeniorhynchus collected from May to September during 1966 and 1973 and the total area of rice fields or the proportion of two-crop fields in Kacho Plain in this period.

There was, also, a high correlation coefficient $(r=0.949)$ between the number of vector mosquitoes collected and the number of Japanese encephalitis patients in Kochi Prefecture during the same period.

The number of vector mosquitoes caught by light traps decreased abruptly from the end of August even when the temperature is around $25^{\circ} \mathrm{C}$. This phenomenon was partly explained from the results of laboratory experiments in which phototaxis and blood feeding behavior of 
adult females were suppressed when the larvae were bred under day length of $10 \mathrm{hr}$ or less at 20 or $25^{\circ} \mathrm{C}$.

The vector mosquito was not found in caves and other places in Kochi Prefecture throughout the winter surveys. Japanese encephalitis virus was not isolated from three other species than $C x$. tritaeniorhynchus collected in winter. 